\title{
Bronchial Asthma: Genetic Factors Contributing to its Pathogenesis
}

 \\ ${ }^{1}$ Department of Functional and Laboratory Diagnostics, I. Horbachevsky Ternopil National Medical University, 46001 Ternopil, \\ Ukraine; ${ }^{2}$ Department of Pathological Anatomy, Autopsy course and Forensic pathology, I. Horbachevsky Ternopil National \\ Medical University, 46001 Ternopil, Ukraine; ${ }^{3}$ Department of Internal Medicine N1, I. Horbachevsky Ternopil National Medical \\ University, 46001 Ternopil, Ukraine; ${ }^{4}$ Department of General Hygiene and Ecology, I. Horbachevsky Ternopil National Medical \\ University, 46001 Ternopil, Ukraine; ${ }^{5}$ Department of Internal Medicine Propedeutics and Phthisiology, I. Horbachevsky Ternopil \\ National Medical University, 46001 Ternopil, Ukraine
}

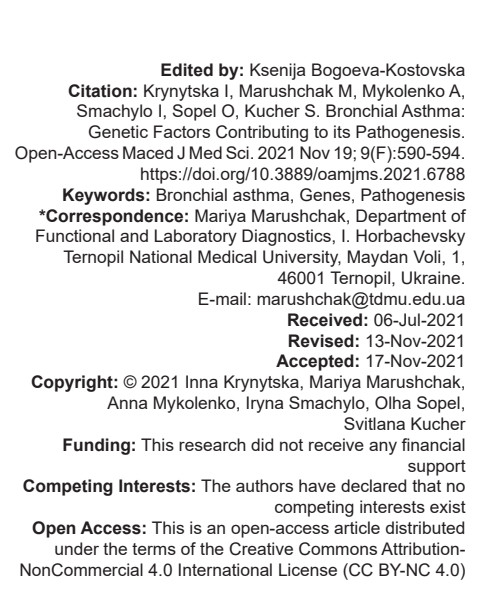

\begin{abstract}
Researching bronchial asthma (BA)-linked gene polymorphisms can help to clarify heterogeneity of the disease and estimate its severity, which, in turn, will aid in developing an appropriate treatment corresponding to the patient's unique asthma pathogenesis. The aim of presented review is to analyze the published data on the genetic preconditions of BA and the possible role of different genes polymorphisms in its pathogenesis. We have found that despite the fact that numerous genes are involved in the pathogenesis of BA and their polymorphisms are associated with increased risks for BA, it is important to understand that a combination of factors, both genetic and environmental, triggers BA development and determines its progression. On the other hand, the identification of BA susceptibility genes contributing to asthma pathogenesis and treatment response is the first step toward the development of personalized medicine.
\end{abstract}

\section{Introduction}

Bronchial asthma (BA) is among the most common chronic inflammatory disorders of the bronchial airways, which gradually results in increased contractibility of the surrounding smooth muscles and deterioration of pulmonary function. Around 300 million people have BA worldwide (including 6 million children), and it is likely that by 2025 , a further 100 million may be affected [1], [2]. It should be noted that almost 10 million people $<45$ years of age have BA in European Union (EU) [3]. BA negatively affects patients' quality of life, their families, and the community by contributing to work and school days' loss, frequent emergency visits and hospitalizations, and increase in mortality.

Globally, BA is currently ranked $16^{\text {th }}$ among the leading causes of years lived with disability and $28^{\text {th }}$ among the leading causes of disease burden, as calculated by disability-adjusted life years (DALYs) [1], [4]. Recent calculations estimate direct costs within the EU to be nearly $€ 20$ billion, indirect costs to be $€ 14$ billion, and a monetized value of DALYs lost to be $€ 38$ billion, which totals $€ 72$ billion [3]. During COVID-19 pandemic, when the outcomes and long-term consequences of an infection considerably vary between individuals [5], BA can be accounted as comorbidity which may worsen the outcomes of COVID-19 infection and increase the risks of admission to intensive care unit [6].

According to the Center for Medical Statistics of the Ministry of Health of Ukraine, the prevalence of BA in 2017 was 501.9/100.000 adults, which is only $0.3 \%$ of the total Ukrainian population and contradicts real-world statistics. According to experts, the real prevalence of BA in Ukraine can reach 7-8\% [7], [8], which corresponds to the prevalence of BA in the EU (8.2\% in adults and $9.4 \%$ in children) [3]. It should be noted that over $80 \%$ of all BA-related deaths now take place in low- and lower-middle-income countries, where BA is often misdiagnosed and undertreated [4].

Although the exact etiology of BA stays uncertain, it became evident that a mixture of genetic 
predisposition and environmental factors are involved in its pathogenesis [9], [10], [11], [12]. Genetic factors contributing to BA appear as a result of complex patterns in haplotype combinations of polymorphic genes. Variation in different groups of genes may influence the development of atopic sensibilization, while other genetic changes contribute as the disorder progresses. As of today, more than 50 different genes have been associated with the development and progression of BA [13]

To search for genetic determinants of $B A$, two general linkage analysis approaches are used: Candidate and positional mapping. For candidate mapping, an analysis is made of the relationship between the BA and the polymorphism of genes, the function of which is closely related to the pathogenesis of this disease. For positional mapping, an analysis is made of the linkage of the disease with the chromosomal position. Chromosomal regions carrying BA susceptibility genes include $5 q 31.1-33,6 p 12-21.2$, $11 q 12-13,12 q 14-24.1,13 q 12-22,14 q 11-12$, and 16p12.1-11.2 и Xq28/Yq12 [14].

To summarize, researching BA-linked gene polymorphisms can help to clarify heterogeneity of the disease and estimate its severity [15], which, in turn, will aid in developing an appropriate treatment corresponding to the patient's unique asthma pathogenesis [16]. Thus, the aim of presented review is to analyze the published data on the genetic preconditions of BA and the possible role of different genes polymorphisms in its pathogenesis.

Genes controlling the pathogenesis of BA are generally categorized as major genes and modifier genes, and their interaction defines asthma clinical features. Modifier genes usually predispose to the development of corresponding diseases and include detoxification system genes, membrane receptors genes, as well as trigger genes, which act as shunts in the cascade of vital biochemical reactions [17]. Among the numerous genes involved in the pathogenesis of BA, Smirnova et al. discerned the following five groups: (1) Genes encoding antigen recognition factors and humoral immune response, such as interleukin genes (IL4, IL5, IL9, and IL13), mast cell growth factor, genes of the main histocompatibility complex (HLAB and HLADR), and $\alpha$-subunit of antigenic T-receptor (TCRA); (2) genes encoding for inflammation mediators, chemokines, and intercellular adhesion molecules, including leukotriene-C4 synthase (LTC4S), 38 platelet activating factor acetyl hydrolase, nitric oxide synthase (NOS1, NOS2, and NOS3), arachidonate-5lipoxygenase, histamine-releasing factor, and others; (3) genes encoding for the receptors binding to external ligand molecules on target cells, such as $\alpha$-chain of the IL4 receptor (IL4RA), $\alpha$-chain of the IL5 receptor (IL5RA), glucocorticoid receptor, $\beta 2$-adrenergic receptor (ADRB2), $\beta$-chain of high-affinity immunoglobulin $E$ receptor (FCER1B), and serotonin receptor (HTR2A); (4) genes encoding intracellular signaling molecules and transcription factors including JAK family tyrosine kinase 1 (JAK1) and tyrosine kinase (JAK3), signal transducer and transcription activator 6 (STAT6), $\beta$-subunit of nuclear transcription factor $Y$, and nuclear factor $\kappa B$ subunit 1 ; and (5) other genes, such as xenobiotic biotransformation genes NAT2, CYP1A, GSTT1, and GSTM1 [18].

A 2008 review by Vercelli suggested a useful classification of BA susceptibility factors: (a) Triggers of the immune response (CD14, IL10, STAT3, and $\mathrm{MHC}$ Class II molecules); (b) regulators of the $\mathrm{T}$ helper 2 differentiation (IL12B, IL4, IL13, STAT6, and IL4RA); (c) factors associated with epithelial organization and function (CCL5, FLG, SPINK5, and GSDML); and (d) factors linked to lung function, airway remodeling, and $B A$ severity (ADRB2, ADAM33, DPP10, and PHF11) [19].

Since BA is a multi-complex chronic disorder characterized by inflammation of airway mucosa, which is influenced by a number of cytokines, it has been suggested that clinical symptoms in BA reflect an imbalance in pro- and anti-inflammatory cytokine levels. It was found that the largest segment of publications consists of research on the relationship between cytokine polymorphism and BA. However, while some research groups demonstrate positive association of certain cytokine polymorphisms with BA, others report contradictory data. For instance, Trajkov et al. examined the association of 22 cytokine gene polymorphisms in the Macedonian population with BA and found protective cytokine polymorphisms for seven cytokine genotypes (IL4 -1098/G: T, tumor necrosis factor [TNF] $\alpha$-238/ G: G, IL2 -330/G: T, IL4 -590/C: T, IFN $\gamma$ utr5644/A: T, IL1 $\beta+3962 / C:$ T, and IL10 -1082/A: G), six cytokine diplotypes, four cytokine haplotypes, and four cytokine alleles [20]. Du et al. examined the associations between the single-nucleotide polymorphisms (SNPs) of IL17, including rs763780 (7488A/G), rs2275913 $(-197 \mathrm{G} / \mathrm{A})$, and rs8193036 (-737C/T), and asthma susceptibility in an Asian population and demonstrated that IL17 rs763780, rs2275913, and rs8193036 SNPs might be associated with asthma susceptibility, and G/A genotype in rs2275913 and TT genotype in rs8193036 of IL-17 may contribute to the increased risk of asthma in Asians [21].

Berenguer et al. showed that IL4-590*CT/TT genotypes were associated with a 2.2-fold increased BA risk (2.4-fold for persistent asthma and 4-fold for moderate-severe asthma), while IL4-590*T allele was linked to a 2-fold risk for BA (2.2-fold for persistent asthma and 3.4-fold for moderate-severe asthma), compared to individuals carrying other IL4-590 C/T genotypes or alleles [22].

TNF $\alpha$ is a potent pro-inflammatory cytokine that mediates the airway inflammatory response in atopic asthma cases. Recent meta-analysis showed that the TNF $\alpha-308 \mathrm{G} / \mathrm{A}$ polymorphism is associated with an increased risk of BA in adults and children, in Asians, but not in Caucasians; and in atopic population, 
but not in non-atopic population [23]. Ali and Settin studied the associations of TNF $\alpha-308 \mathrm{G} / \mathrm{A}$, IL6-174G/C, IL-10 1082G/A, and IL-Ra VNTR polymorphisms with chronic asthma susceptibility in adult Egyptian patients [24]. The researchers found significantly higher frequency of the genotypic polymorphisms IL10$1082 \mathrm{AG}+\mathrm{GG}$ (dominant mode), TNF $\alpha-308 \mathrm{GA}+\mathrm{AA}$ (dominant mode), and IL1RA VNTR heterozygous genotype A1A2 in BA cases compared to controls. The frequency difference in other genotypes, such as IL6$174 \mathrm{C} / \mathrm{C}+\mathrm{G} / \mathrm{C}$ versus $\mathrm{G} / \mathrm{G}$ (dominant mode), was not significant.

Forkhead box (FOX) family of transcription factors has key roles in immunoregulation and homeostasis [25]. A study by Barkund et al. showed that FOXO3a SNP (rs13217795) is associated with asthma incidence in an Indian population, possibly because it contributes to the hyperactivity of $\mathrm{T}$ cells, neutrophils, and mast cells, increased production of pro-inflammatory cytokines, and downregulation of anti-inflammatory cytokines [26]. In addition, to the significant association of $\mathrm{FOXO} 3 \mathrm{a}$ with $\mathrm{BA}$, a genderbased stratification revealed the association of a mutant $T$ allele with an increased asthma risk in females of the Indian population.

Airway obstruction, characteristic to BA, results in impaired air movement, which not only requires additional physical effort during respiration but also induces remodeling mechanisms of the bronchopulmonary system [27]. An important role in this process is played by matrix metalloproteinases (MMPs), involved in the metabolism of proteins of the intercellular matrix. As cytokine proteinases, they affect the morphogenesis, resorption, migration, adhesion, and proliferation of various cells and tissues [28].

A study by Lebedenko et al. found higher frequency of homozygous C/C MMP20 gene variant with 320A $>$ C polymorphism, heterozygous MMP20 gene variant Val275Ala, and heterozygous MMP9 gene variant with $-8202 A>G$ polymorphism in patients with BA [27]. However, the frequencies of these alleles and genotypes were not significantly different in the affected children while comparing to the healthy group. Notably, the patients who had both GG genotype of the MMP9 -8202A $>\mathrm{G}$ allele and homozygous C-allele of the $320 A>C$ allele of the MMP20 gene suffered from a more severe course of the disease associated with polyvalent sensitization and increased levels of total blood lgE.

The beta-2 adrenergic receptor gene (ADRB2) was shown to have clear association with the course of BA. It encodes $\beta-2$ adrenergic receptors, has nine identified polymorphisms, and is located on chromosome 5 q31-q32. Four of those polymorphisms have potential clinical effects on the response to $\beta-2$ adrenoreceptor agonist therapy in asthmatic patients [29], [30]. Arg16Gly and Glu27GIn ADRB2 polymorphisms are associated with increased risk of severe asthma development [12]. Moreover, patients which are homozygous for these gene variants rapidly lose sensitivity to $\beta 2$-adrenoceptor agonists resulting in required treatment with hormonal drugs [31].

Glutathione S-transferase (GST) gene family encodes for enzymes which are involved in antioxidant protection and cell and tissue resistance to toxic substances and lipid peroxidation products [32]. A study by Sardaryan found that allelic polymorphism of GST T1 (GSTT1) and GST M1 (GSTM1) genes caused a 5-fold increase in the risk for BA development [17].

The angiotensin-converting enzyme (ACE) gene polymorphism may also play a major role in BA pathogenesis and has been a focus of numerous epidemiological studies; however, so far, the results are currently inconclusive. The ACE gene is located on the q23 locus of chromosome 17 . Individual variability in the plasma ACE levels is associated with a presence [insertion (I)] or absence [deletion (D)] of a 250 bp region located in the intron 16 of the ACE gene, which is known as the ACE I/D polymorphism. Three genotypes of ACE I/D polymorphism are known: Deletion homozygote, D/D; insertion homozygote, I/l; and heterozygote, D/I [33], [34].

Ding et al. showed that human subjects with the D/D genotype of ACE gene polymorphism had increased BA risk compared to those with the $\mathrm{I} / \mathrm{I}$ genotype or I/D [35]. Iskandar et al. showed that $A C E$ D/D genotype had significantly higher occurrence in atopic asthmatic patients, compared to healthy control subjects; patients with D/D genotype had 6.8-fold higher risk for atopic asthma development than those with nonD/D genotype [36]. Pasiyeshvili and Zheleznyakova showed that the relative risk of developing BA was 2.67 for patients with the ACE D/D genotype; 0.46 for the ACE D/l genotype; and 0.69 for the ACE I/I genotype, suggesting a possible protective role of the I allele [37]. The authors point out that individuals carrying ACE D/D genotype predominate $(54.2 \%)$ among BA patients. This is also supported by a study indicating that children with the D/D genotype are in the group of high risk for BA development [38].

On the other hand, some studies failed to establish any associations of ACE gene polymorphisms with BA. For instance, ACE gene polymorphism is not significantly associated with BA or with its severity among Egyptian adults [39]. Similarly, the ACE genotype frequencies also do not significantly differ between the patients with BA and healthy controls in study conducted in Turkey [40], Iran [41], and Japan [42].

\section{Conclusion}

The literature review gives some insights to the conclusion that not a single factor alone 
contributes to the development and progression of $B A$, as contribution of ACE I/D polymorphism may be controversial and depends on other factors, both genetic and environmental. For example, a specific single-nucleotide polymorphism in the CD14 region contributes to asthma development only after exposure to endotoxin at a certain level, which may come from several environmental sources [43]. Although the overall conclusion is that despite the fact that numerous genes are involved in the pathogenesis of BA and their polymorphisms are associated with increased risks for $\mathrm{BA}$, it is important to understand that a combination of factors, both genetic and environmental, triggers BA development and determines its progression. On the other hand, the identification of BA susceptibility genes contributing to asthma pathogenesis and treatment response is the first step toward the development of personalized medicine.

\section{References}

1. Shine S, Muhamud S, Demelash A. Prevalence and associated factors of bronchial asthma among adult patients in Debre Berhan Referral Hospital, Ethiopia 2018: A cross-sectional study. BMC Res Notes. 2019;12(1):608. http://doi.org/10.1186/ s13104-019-4670-9

PMid:31547859

2. Dharmage SC, Perret JL, Custovic A. Epidemiology of asthma in children and adults. Front Pediatr. 2019;7:246. http://doi. org/10.3389/fped.2019.00246

PMid:31275909

3. Selroos O, Kupczyk M, Kuna P, Łacwik $P$, Bousquet $J$, Brennan D, et al. National and regional asthma programmes in Europe. Eur Respir Rev. 2015;24(137):474-83. http://doi. org/10.1183/16000617.00008114

PMid:26324809

4. Nugmanova D, Sokolova L, Feshchenko Y, lashyna L, Gyrina O, Malynovska $\mathrm{K}$, et al. The prevalence, burden and risk factors associated with bronchial asthma in commonwealth of independent states countries (Ukraine, Kazakhstan and Azerbaijan): Results of the CORE study. BMC Pulm Med. 2018;18(1):110. http://doi.org/10.1186/s12890-018-0676-7 PMid:29976177

5. Kamyshnyi A, Krynytska I, Matskevych V, Marushchak M, Lushchak $O$ Arterial hypertension as a risk comorbidity associated with COVID-19 pathology. Int J Hypertens. 2020;2020:8019360. http://doi.org/10.1155/2020/8019360 PMid:33489355

6. Lee SC, Son KJ, Han CH, Jung JY, Park SC. Impact of comorbid asthma on severity of coronavirus disease (COVID-19). Sci. Rep. 2020;10(1):21805.

PMid:33311519

7. Velichko VI, Bazhora Yal, Danilchuk GO. Prevalence of comorbid states and modified risk factors in patients with bronchial asthma. Fam Med. 2019;1(81):119-22. http://doi. org/10.30841/2307-5112.1.2019.172330

8. Volosovets OP, Bolbot YK, Kryvopustov SP, Mozyrska OV, Kryvopustova MV, Prokhorova MP, et al. Bronchial asthma in children of Ukraine: Medical and environmental parallels of morbidity and prevalence. Med Perspect. 2020;25(3):184-91. https://doi.org/10.26641/2307-0404.2020.3.214861

9. Zhu Y, Yan X, Zhai C, Yang L, Li M. Association between risk of asthma and gene polymorphisms in CHI3L1 and CHIA: A systematic meta-analysis. BMC Pulm Med. 2017;17(1):193. https://doi.org/10.1186/s12890-017-0515-2

PMid:29233108

10. Ober $\mathrm{C}$, Yao TC. The genetics of asthma and allergic disease: A $21^{\text {st }}$ century perspective. Immunol Rev. 2011;242(1):10-30. https://doi.org/10.1111/j.1600-065X.2011.01029.x

PMid:21682736

11. Dayasiri $\mathrm{K}$, Thadchanamoorthy $\mathrm{V}$, Thisanayagam U. Diagnosis and management of allergic rhinitis in children. Int $\mathrm{J}$ Human Health Sci. 2021;5(2):159-62. https://doi.org/10.31344/ijhhs. v5i2.253

12. Xu W, Wang $Y$, Wang $C$, Ma $Y$, He S, Kang Y, et al. Increased miR-223-3p in leukocytes positively correlated with IL-17A in plasma of asthmatic patients. Iran J Allergy Asthma Immunol. 2020;19(3):289-96. https://doi.org/10.18502/ijaai.v19i3.3456 PMid:32615662

13. Ober C, Hoffjan S. Asthma genetics 2006: The long and winding road to gene discovery. Genes Immun. 2006;7(2):95-100. https://doi.org/10.1038/sj.gene.6364284 PMid: 16395390

14. Uryas'ev OM, Shakhanov AV. Role of nitric oxide synthases polymorphism in the development of comorbidity of bronchial asthma and hypertension. Kazan Med J. 2017;98(2):226-32.

15. Meyers DA, Bleecker ER, Holloway JW, Holgate ST Asthma genetics and personalised medicine. Lancet Respir Med. 2014;2(5):405-15. https://doi.org/10.1016/ S2213-2600(14)70012-8 PMid:24794577

16. Huo Y, Zhang HY. Genetic mechanisms of asthma and the implications for drug repositioning. Genes. 2018;9(5):237. https://doi.org/10.3390/genes9050237 PMid:29751569

17. Sardaryan I. Phenotypic Features of Bronchial Asthma in Children with Various Allelic Polymorphisms of "Predisposition" Genes (GSTT1, GSTM1, ACE, eNOS) [Dissertation]. Saint Petersburg; 2009.

18. Smirnova A, Gnoevykh V, Portnova J. Genetic aspects of multifactorial chronic bronchial obstructive diseases. Ul'yanovskiy Med Biol J. 2014;1:8-18

19. Vercelli D. Discovering susceptibility genes for asthma and allergy. Nat Rev Immunol. 2008;8(3):169-82. https://doi. org/10.3390/genes $905023710.1038 /$ nri2257 PMid: 18301422

20. Trajkov D, Mirkovska-Stojkovikj J, Arsov T, Petlichkovski A, Strezova A, Efinska-Mladenovska O, et al. Association of cytokine gene polymorphisms with bronchial asthma in Macedonians. Iran J Allergy Asthma Immunol. 2008;7(3):143-56. PMid:18780949

21. Du J, Han JC, Zhang YJ, Qi GB, Li HB, Zhang YJ, et al. Singlenucleotide polymorphisms of IL-17 gene are associated with asthma susceptibility in an Asian population. Med Sci Monit. 2016;22:780-7. https://doi.org/10.12659/msm.895494 PMid:26954344

22. Berenguer AG, Fernandes AT, Oliveira $S$, Rodrigues $M$, Ornelas $P$, Romeira D, et al. Genetic polymorphisms and asthma: Findings from a case-control study in the Madeira island population. Biol Res. 2014;47(1):40. https://doi.org/10.1186/0717-6287-47-40 PMid:25299150

23. Zhang Y, Zhang J, Tian C, Xiao Y, He C, Li X, et al. The 308 G/A polymorphism in TNF-alpha gene is associated with 
asthma risk: An update by meta-analysis. J Clin Immunol. 2011;31(2):174-85.

PMid:21082225

24. Ali A, Settin A. Molecular genetic analysis of polymorphisms pertaining to the susceptibility to chronic asthma in Egyptian patients. JOBAZ. 2013;66(4):188-94. https://doi.org/10.1016/j. jobaz.2013.05.001

25. Lee JC, Espeli M, Anderson CA, Linterman MA, Pocock JM, Williams NJ, et al. Human SNP links differential outcomes in inflammatory and infectious disease to a FOXO3-regulated pathway. Cell. 2013;155(1):57-69. https://doi.org/10.1016/j. cell.2013.08.034

PMid:24035192

26. Barkund S, Shah T, Ambatkar N, Gadgil M, Joshi K. FOXO3a gene polymorphism associated with asthma in Indian population. Mol Biol Int. 2015;2015:638515. https://doi. org/10.1155/2015/638515

PMid:26783460

27. Lebedenko A, Shkurat T, Mashkina E, Semernik O, Dreyzina T, Tyurina E. Association of matrix metalloproteinases gene polymorphism with clinical manifestations of bronchial asthma in children. Med Immunol (Russia). 2018;20(6):905-12.

28. Fanjul-Fernandez M, Folgueras AR, Cabrera S, Lopez-Otin C. Matrix metalloproteinases: Evolution, gene regulation and functional analysis in mouse models. Biochim Biophys Acta. 2010;1803(1):3-19. https://doi.org/10.1016/j. bbamcr.2009.07.004

PMid:19631700

29. Almomani BA, Al-Eitan LN, Al-Sawalha NA, Samrah SM, Al-Quasmi MN. Association of genetic variants with level of asthma control in the Arab population. J Asthma Allergy. 2019;12:35-42. https://doi.org/10.2147/JAA.S186252 PMid:30774389

30. Hikino K, Kobayashi S, Ota E, Mushiroda T, Kobayashi T. The influence of beta-2 adrenergic receptor gene polymorphisms on albuterol therapy for patients with asthma: Protocol for a systematic review and meta-analysis. JMIR Res Protoc. 2019;8(9):e14759. https://doi.org/10.2196/14759

PMid:31538939

31. Wechsler ME, Lehman E, Lazarus SC, Lemanske RF, Boushey HA, Deykin A, et al. beta-Adrenergic receptor polymorphisms and response to salmeterol. Am J Respir Crit Care Med. 2006;173(5):519-26.

PMid:16322642

32. Marushchak M, Maksiv K, Krynytska I, Stechyshyn I. Glutathione antioxidant system of lymphocytes in the blood of patients in a setting of concomitant chronic obstructive pulmonary disease and arterial hypertension. Pol Merkur Lekarski. 2019;47(281):177-82.

PMid:31812971

33. Jung SK, Ra J, Seo J, Jung HJ, Choi JY, Cho YJ, et al. An
Angiotensin I converting enzyme polymorphism is associated with clinical phenotype when using differentiation-syndrome to categorize Korean bronchial asthma patients. Evid Based Complement Alternat Med. 2011;2011:498138.

PMid:19525331

34. Marushchak M, Maksiv K, Krynytska I. ACE gene I/D polymorphism and arterial hypertension in patients with COPD. Pneumologia. 2019;68(3):114-9.

35. Ding QL, Sun SF, Cao C, Deng ZC. Association between angiotensin-converting enzyme I/D polymorphism and asthma risk: A meta-analysis involving 11,897 subjects. J Asthma. 2012;49(6):557-62. https://doi.org/10.3109/02770 903.2012.685540 PMid:22741763

36. Iskandar H, Bakri S, Mannulusi B, Patellongi IJ. DD genotype of the I/D angiotensin-converting enzyme gene polymorphism is a higher risk for atopic asthma. Int $\mathrm{J}$ Med Rev Case Rep. 2020;4(5):11-4.

37. Pasiyeshvili T, Zheleznyakova N. Clinical and prognostic value of ACE gene polymorphism in patients with asthma and obesity. Crimean Ther J. 2015;1:65-8.

38. Rechkina O, Gorovenko N, Stryzh V, Rossokha Z, Kyriachenko $S$, Rudenko $S$. Models of gen-gene interaction in determining the severity of bronchial asthma in children. Am J Intern Med. 2020;8(4):182-91.

39. El-Shafei MS, Farres MN, Shahin RY. Evaluation of angiotensin converting enzyme gene polymorphism and susceptibility to bronchial asthma among Egyptians. Allergol Immunopathol (Madr). 2012;40(5):275-80. https://doi.org/10.1016/j. aller.2011.05.010

PMid:21889830

40. Bora E, Soylar R, Arıkan-Ayyıldız Z, Uzuner N, Giray-Bozkaya Ö, Erçal D, et al. Plasminogen activator inhibitor-1 and angiotensin converting enzyme gene polymorphisms in Turkish asthmatic children. Allergol Immunopathol (Madr). 2013;41(1):11-6. https://doi.org/10.1016/j.aller.2011.12.003

PMid:22361338

41. Alizadeh-Navaei R, Rafiei A, Hedayatizadeh-Omran A, Mohammadzadeh I, Arabi M. Gene susceptibility in Iranian asthmatic patients: A narrative review. Ann Med Health Sci Res. 2014;4(6):837-40. https://doi.org/10.4103/2141-9248.144871 PMid:25506473

42. Nakahama $H$, Obata $K$, Nakajima $T$, Nakamura $H$, Kitada $O$, Sugita $M$, et al. Renin-angiotensin system component gene polymorphism in Japanese bronchial asthma patients. J Asthma. 1999;36(2):187-93. https://doi. org/10.3109/02770909909056316

PMid: 10227270

43. Martinez FD. CD14, endotoxin, and asthma risk: Actions and interactions. Proc Am Thorac Soc. 2007;4(3):221-5. https://doi. org/10.1513/pats.200702-035AW

PMid:17607003 